\title{
The effectiveness of Cosmetic Product Advertising Using EPIC Model Through Beauty Vlogger on Youtube
}

\author{
Rahmat Hidayat, Harrie Lutfie \\ \{rahmathidayat@tass.telkomuniversity.ac.id ${ }^{1}$, harrie.lutfie@gmail.com ${ }^{2}$ \} \\ Telkom Applied Science School, Marketing Program Study, Telkom University, Bandung, \\ Indonesia ${ }^{1,2}$
}

\begin{abstract}
The rapid technological development demands a change in the marketing strategy of a product in order to thrive and survive sustainably. Cosmetics business is currently growing so rapidly proved increasingly mushrooming companies that produce cosmetics for personal use impact on business competition so hard. Wardah cosmetics that produce cosmetics, especially for personal purposes also feel the competition is so tight. However, the problem relates to how cosmetic products can be marketed so that the effectiveness of the advertisement can be perfect and the demand by consumers is still the main topic. In this research used survey method by using research object on Bandung society cosmetic product user by analyzing the effectiveness of advertisement using EPIC model through Vlogger by using descriptive analysis as analytical tool consisting of Dimension Empathy, Persuasion, Impact And Communication. The results showed that all dimensions of EPIC with an average score above 3.50 which means that overall is in quadrant IV means to show that all dimensions in the EPIC model are effective. Thus it can be said that the use of EPIC methods in measuring the effectiveness of advertising through vloggers is very good. The deeper finding that the Communication dimension has the greatest value compared to other dimensions while the smallest dimension is in empathy. Other findings of all dimensions in EPIC still have not achieved perfect effectiveness (quadrant $\mathrm{V}$ ) because they are still between IV quadrants. Based on the above findings then the company producing personal needs (cosmetics) in order to improve the effectiveness of its ads and pay attention to the above dimensions, especially on the dimensions of empathy that occupy the smallest score.
\end{abstract}

Keywords: Emphaty, Persuasion, Impact, Communication.

\section{Introduction}

Cosmetics are the care substances used to enhance the appearance or aroma of the human body. Cosmetics are generally a mixture of various chemical compounds, some made from natural sources and mostly from synthetic materials[1]. Cosmetics are used to beautify or beautify oneself used by women. Now cosmetics are not only used by adult women, but young people with an average age of 15 years have started using it. Formerly used cosmetics at certain occasions, but along with the development of cosmetics into daily needs that can not be separated from the lifestyle of people who use makeup itself. In Indonesia there are many different types of cosmetic brands sold, including Wardah Cosmetic, Maybelline, Make Over, Sari Ayu, PIXY and other brands of cosmetics. They compete with their respective advantages. 
As Wardah does, he refers to the halalness of the product and has the main target of Muslim women who wear a headscarf. With so many companies that sell cosmetics then the company must have a good promotional strategy for example through advertising media.

Technological developments increasingly rapidly affect the increasingly striking lifestyles, seen from the increasing need for technology in all things, including in promoting a product in the form of Ads. The widespread media promotion certainly facilitates the producers to enter the scope of consumers. Manufacturers can enter the scope of consumers from all sectors ranging from Social Media (Instagram, YouTube, Twitter), Media Visual (Television), NonVisual Media (Radio), and others. The most effective medium to be used as a media campaign for advertising at this time is Youtube, by uploading promotional videos on Youtube we can already disseminate information to consumers.

YouTube seems to be more successful to become the most loved media spectacle. This can be seen from the duration spent by users to watch the various videos every day[2]. According to Vice President of Engineering YouTube, Cristos Goodrow, the duration of people watching videos on the platform has increased dramatically. The total reaches 1 billion hours per day. The number of youtube users in Indonesia according to APJII data in 2016 is $11 \%$ of total internet users Indonesia which means there are as many as 14.5 million youtube users in Indonesia [3]. Opportunities are what makes the author interested in the reasons why people want to promote themselves or a product in the form of videos uploaded on youtube.

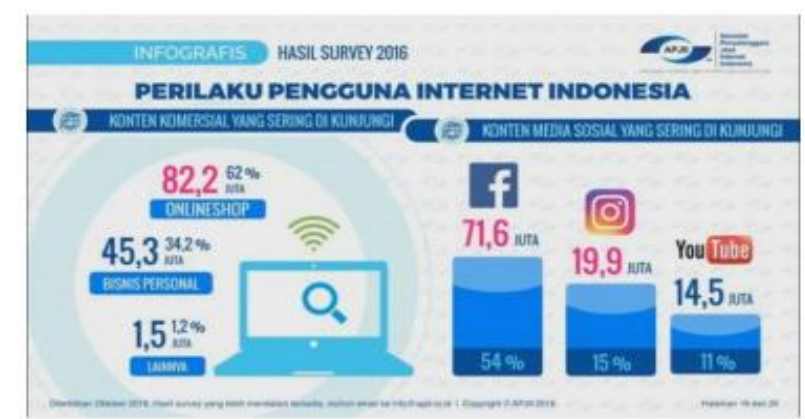

Fig. 1. Frequently Visited Social Media Content (apjii.or.id, 2017)

But on the other side, youtube is the lowest user of internet usage of Indonesia compared to Facebook $(54 \%)$ and Instagram (15\%), eventhought like that, some research said that ads delivered by youtube can improve purchasing decisions of customer[4].

In this day and age, we live in a world where individuals can promote themselves on social media

and various youtube video platforms as vloggers. Vloggers are able to make buying intentions increase for watching customers than those who are not watching[5] and video ads created by beauty vlogger there is a strong enough and confident relationship, so the better Video Ads by Beauty Vlogger made and distributed the higher the tendency of consumers interested in buying for one of brand of cosmetics[6]. The proliferation of youtube users is increasing every year as evidenced by calculations that can increase the percentage of YouTube viewers to 130 percent taken from Vice President of Engineering for Emerging Experience YouTube John Harding at Google for Indonesia event. All industries, especially the beauty industry began to glance at the beauty vlogger stars on youtube because, according to a quote from Marketeers magazine, they believe in the power that beauty vloggers have in "hypnotizing" their audiences. Because the women are now looking for someone who is able to say what it is, 
and well understood with the world of beauty and all the characters that can be found on the figure of a beauty vlogger. Beauty vlogger is someone who promotes a beauty product by uploading it on youtube and doing tutorials or how to use the product and then packed in a video uploaded on the youtube platform. Vlogger it self stands for video blogger, which is currently famous in the world of Youtube.

Another factor of the development of wardah cosmetics marketing proved good where cosmetic wardah products especially cosmetic foundation, face powder, and solid face powder is in great demand by consumers, this is evident through a survey conducted by Frontier in 2017 showed that the above cosmetics wardah products occupy the first position Top Brand Image (TBI) as shown in the table below.

\begin{tabular}{lcc}
\multicolumn{3}{c}{ Face Cleansing } \\
\hline \multicolumn{1}{c}{ Brand } & TBI & TOP \\
\hline Pond`s & $28.6 \%$ & TOP \\
Garnier & $12.5 \%$ & TOP \\
Viva & $11.8 \%$ & TOP \\
Sariayu & $6.2 \%$ & \\
Ovale & $4.7 \%$ & \\
Wardah & $4.5 \%$ & \\
\hline
\end{tabular}

\begin{tabular}{lcc}
\multicolumn{3}{c}{ Table 1. Top Brand Index } \\
Masker for Face \\
\hline \multicolumn{1}{c}{ Brand } & TBI & TOP \\
\hline Sariayu & $23.2 \%$ & TOP \\
Ovale & $22.8 \%$ & TOP \\
Viva & $10.7 \%$ & TOP \\
Mustika Ratu & $10.7 \%$ & \\
Garnier & $7.0 \%$ & \\
Wardah & $5.8 \%$ & \\
\hline
\end{tabular}

\begin{tabular}{lcc}
\multicolumn{3}{c}{ Anti Aging } \\
\hline \multicolumn{1}{c}{ Brand } & TBI & TOP \\
\hline Pond`s & $45.6 \%$ & TOP \\
Olay Total & $15.7 \%$ & TOP \\
Effect & & \\
Garnier & $13.4 \%$ & TOP \\
Wardah & $6.1 \%$ & \\
L Oreal & $3.5 \%$ & \\
\hline
\end{tabular}

On the other hand, marketing of other cosmetic wardah products is not as smooth as cosmetic products above the frontier survey results of 2017 shows that cosmetic wardah products such as facial cleanser, facial mask and anti-aging tops the lowest Image Brand compared to other products.

Tabel 2. Top Brand Index (Frontier Top Brand Index 2017)

\begin{tabular}{|c|c|c|c|c|c|c|c|c|}
\hline \multicolumn{3}{|c|}{ Foundation } & \multicolumn{3}{|c|}{ Tabur Face Powder } & \multicolumn{3}{|c|}{ Solid Face Powder } \\
\hline Brand & TBI & TOP & Brand & TBI & TOP & Brand & TBI & TOP \\
\hline Wardah & $23.1 \%$ & TOP & Wardah & $17.0 \%$ & TOP & Wardah & $26.0 \%$ & TOP \\
\hline Revlon & $11.9 \%$ & TOP & Viva & $16.0 \%$ & TOP & Pixy & $15.7 \%$ & TOP \\
\hline Sariayu & $6.1 \%$ & & Marcks & $11.6 \%$ & TOP & Viva & $6.0 \%$ & \\
\hline La Tulipe & $5.1 \%$ & & Sariayu & $8.0 \%$ & & Sariayu & $7.8 \%$ & \\
\hline Viva & $4.3 \%$ & & Pixy & $6.7 \%$ & & La Tulipe & $6.4 \%$ & \\
\hline Oriflame & $3.6 \%$ & & La Tulipe & $4.2 \%$ & & Maybelline & $5.3 \%$ & \\
\hline
\end{tabular}

By looking at the above phenomenon we see some interest in cosmetic brand using beauty vlogger as a media promotion of a cosmetic brand. Therefore, the authors are interested to conduct research about the The effectiveness of Cosmetic Product Advertising Using EPIC Model Through Beauty Vlogger on Youtube.

\section{Extension-Rule Based Theorem Proving Method}

\subsection{Ad Effectiveness}

Promotion mix consists of 5 promotional tools, one of which is advertising that is all forms of presentation and nonpersonal promotion paid by the sponsor to present the idea of good goods and services [7]. Advertising is a media that companies use to remind, persuade and inform [8] 
and Advertising also defined as a form of expenditure for non-personal communications regarding organizations, products, services or other ideas identified by sponsors[9]. The effectiveness of advertising, in general, the ultimate goal of a commercial advertising is purchasing. Most advertisers try to measure the effect of an advertisement's communication that is a potential influence on awareness, knowledge or preference and can also affect sales. Effective advertising alone can be judged as a form of corporate success in capturing the audience's attention [10].

\subsection{EPIC model}

The EPIC Model is one of the ad effectiveness tools with a communication approach developed by AC Nielsen - one of the world's leading marketing research companies - that includes four critical dimensions: empathy, persuasion, impact, and communication (Empathy, Persuasion, Impact, and Communication - EPIC). The following dimensions will be exposed in the EPIC model [11]:

\subsection{Dimension of Empathy}

Empathy is a mental state that enables a person to identify himself or feel himself in the same state of mind or feeling with other people or groups. The dimensions of empathy inform, whether the consumer likes an advertisement and describes how consumers see the relationship between an advertisement with their personal. From many studies, saying that empathy which is a sub-variable of service quality, has an influence on repurchase interest [12] and emphaty also can increase of purchase decision[13]

\subsection{Persuasion Dimension}

Persuasion is a change in beliefs, attitudes, and desire to behave that caused a promotional communication. The process of persuasion to be used is determined by the level of consumer involvement in product messages. The Persuasion Dimension tells what an advertiser can offer to increase or strengthen a brand's character so that advertisers gain an understanding of the impact of advertising on consumers' desire to buy and gain an idea of the ability of an ad to develop a brand's appeal. Persuasion through brand image can increase consumer buying interest [14]

\subsection{Impact Dimensions}

The desired impact of the advertising result is the amount of product knowledge the consumer achieves through the level of consumer involvement with the product or the selection process. The Impact dimension shows whether a brand can stand out from other brands in a similar category; and whether the ad is able to engage consumers in the delivered message. Knowledge of products that are part of the brand image has a positive relationship to the buying interest, the more up the brand image is also increasing variable buying interest Persuasive through brand image can increase consumer buying interest [15] 


\subsection{Communication Dimensions}

Communication provides information about the ability of consumers to remember the main message conveyed, consumer understanding, and the power of impression left by the message. The cognitive processing perspective is central to developing a successful marketing strategy that is a communication issue.

\subsection{Framework}

The framework is a general description of the problem in order to clarify problem-solving based on the theory used. In this framework, we illustrate the pattern of relationships between dimensions using the EPIC method and which affect in the effectiveness of Media Advertising and Purchase Decisions. The following figure below shows the relationship pattern.

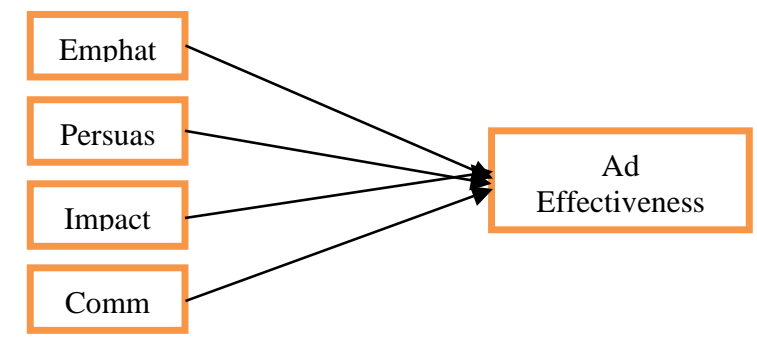

Fig. 2. EPIC Model

\section{Parallel Proving Algorithm Based On Semi-Extension Rule}

Measurement scale is an agreement that is used as a reference to determine the short length of intervals that exist in the measuring instrument, as the measuring tool when used in the measurement will produce quantitative data. The scale we used in this research is ordinal scale in the form Likert scale [16].

Table 3. Measurement Scale Model

\begin{tabular}{lc}
\hline \multicolumn{1}{c}{ Level } & Score \\
\hline Strongly agree & 1 \\
Agree & 2 \\
Netral & 3 \\
Disagree & 4 \\
Strongly disagree & 5 \\
\hline
\end{tabular}

The method used in this research is to use qualitative and quantitative descriptive method through field survey to see the relationship between influencing variables. Given the number of consumers using cosmetic wardah products can be said is not limited than the formula used to calculate the number of samples required to represent the consumer population of cosmetic wardah products using the formula Bernoulli:

$$
n \geq \frac{[Z \alpha / 2] 2 \rho . q}{e^{2}}
$$


Where:

$\mathrm{N}=$ Minimum sample size

$\mathrm{Z}=$ Normal distribution table value

$\mathrm{A}=$ Significant level

$\mathrm{P}=$ Proportion of valid number of questionnaires

$\mathrm{Q}=$ Proportion of invalid number of questionnaires

$\mathrm{E}=$ fault tolerance

In this case, the researcher uses a 95\% confidence level and a 5\% accuracy level. The error rate is $10 \%$ and the probability of being accepted and rejected is $50 \%$, then the $\mathrm{Z}$ value is $\mathrm{Z}=$ 1.96. Thus the minimum required sample size is equal to:

$$
\begin{aligned}
& n \geq \frac{[1,96]^{2} 0,5.0,5}{0,1^{2}} \\
& n \geq \frac{[1,96]^{2} 0,5.0,5}{0,1^{2}} \\
& n \geq 96,04
\end{aligned}
$$

The result of the minimum calculation of the required sample amounted to 96.04 respondents. Given in the dissemination and filling questionnaire is quite complicated than to simplify the return questionnaire then the number of respondents increased to 100 respondents.

In this research the range of liker scale used is a scale of 1 to 5 , then to calculate the scale range perform analysis by using simple tabulation by using formula [11]:

Where :

$$
R s=R(\text { bobot }) / \mathrm{M}
$$

Rs $=$ Scale Range

$\mathrm{R}=\mathrm{R}$ (biggest weight) $-\mathrm{R}$ (least weight)

$M=$ number of weight categories

Then Rs (Range Scale) required in Likert scale above is:

$$
\mathrm{Rs}=(5-1) / 5=0,8
$$

The following table is a range of decision scales to determine the effectiveness of ads through Vlogger:

Table 4. Epic Scale Range

\begin{tabular}{ccl}
\hline Scale & Quadran & \multicolumn{1}{c}{ Criteria } \\
\hline $1.0-1.80$ & I & Very ineffective \\
$1.81-2.60$ & II & Ineffective \\
$2.61-3.40$ & III & Enough effective \\
$3.41-4.20$ & IV & Effective \\
$4.20-5.00$ & V & Very effective \\
\hline
\end{tabular}




\section{Experimental Result}

In this study perform a descriptive analysis to see how far the effectiveness of advertising through Vlogger for wardah cosmetic products in Bandung. By using a simple tabulation formula, it can be obtained a picture as follows:

\subsection{Empathy Dimension}

Based on the questionnaire for empathy dimension, it can be known how far the relationship between the answers to the question and the effectiveness of advertising through the weight and frequency. The table below shows the frequency level for each attribute empathy.

Table 5 Frequency Dimensi Emphaty

\begin{tabular}{lccccc}
\hline \multirow{2}{*}{\multicolumn{1}{c}{ Attribute }} & \multirow{2}{*}{ Weight } & \multicolumn{4}{c}{ Frequency } \\
\cline { 3 - 6 } & & E1 & E2 & E3 & E4 \\
\hline Strongly agree & 1 & 5 & 5 & 1 & 3 \\
Agree & 2 & 25 & 11 & 13 & 11 \\
Netral & 3 & 17 & 18 & 25 & 22 \\
Disagree & 4 & 46 & 54 & 37 & 39 \\
Strongly disagree & 5 & 7 & 12 & 24 & 25 \\
$\quad$ Amount & & 100 & 100 & 100 & 100 \\
\hline
\end{tabular}

Based on the above table it can be calculated the average score to determine the level of effectiveness of ads on empathy dimensions:

$$
\begin{aligned}
& \mathrm{E} 1=[(1 \times 5)+(2 \times 25)+(3 \times 17)+(4 \times 46)+(5 \times 7)] / 100=3,25 \\
& \mathrm{E} 2=[(1 \times 5)+(2 \times 11)+(3 \times 18)+(4 \times 54)+(5 \times 12)] / 100=3,57 \\
& \mathrm{E} 3=[(1 \times 1)+(2 \times 13)+(3 \times 25)+(4 \times 37)+(5 \times 24)] / 100=3,7 \\
& \mathrm{E} 4=[(1 \times 3)+(2 \times 11)+(3 \times 22)+(4 \times 39)+(5 \times 25)] / 100=3,68
\end{aligned}
$$

The average score of ad effectiveness rate for empathy dimension is:

$$
\text { Emphaty }=(3,25+3,57+3,70+3,68) / 4=3,55
$$

Thus, the empathy dimension has a value of 3.55 between the IV quadrants, which means that the empathy dimension is in the effective criteria.

\subsection{Persuasion Dimension}

Based on the results of data processing frequency of a number of questionnaires then obtained frequency calculation results as shown below table for the dimension of persuasion. 
Table 6. Dimensi of Persuasion Frequency

\begin{tabular}{lccccccc}
\hline \multirow{2}{*}{ Attribute } & \multirow{2}{*}{ Weight } & \multicolumn{9}{c}{ Frequency } \\
\cline { 3 - 8 } & & P1 & P2 & P3 & P4 & P5 & P6 \\
\hline Strongly agree & 1 & 1 & 1 & 0 & 0 & 1 & 2 \\
Agree & 2 & 11 & 7 & 10 & 15 & 16 & 17 \\
Netral & 3 & 22 & 20 & 18 & 29 & 24 & 35 \\
Disagree & 4 & 43 & 44 & 48 & 36 & 33 & 34 \\
Strongly disagree & 5 & 24 & 28 & 24 & 20 & 26 & 12 \\
$\quad$ Amount & & 100 & 100 & 100 & 100 & 100 & 100 \\
\hline
\end{tabular}

The calculation of the average score is as follows:

$$
\begin{aligned}
& \mathrm{P} 1=[(1 \times 1)+(2 \times 11)+(3 \times 22)+(4 \times 42)+(5 \times 24)] / 100=3,77 \\
& \mathrm{P} 2=[(1 \times 1)+(2 \times 7)+(3 \times 20)+(4 \times 44)+(5 \times 28)] / 100=3,91 \\
& \mathrm{P} 3=[(1 \times 0)+(2 \times 10)+(3 \times 18)+(4 \times 48)+(5 \times 24)] / 100=3,86 \\
& \mathrm{P} 4=[(1 \times 0)+(2 \times 15)+(3 \times 29)+(4 \times 36)+(5 \times 20)] / 100=3,61 \\
& \mathrm{P} 5=[(1 \times 1)+(2 \times 16)+(3 \times 24)+(4 \times 33)+(5 \times 26)] / 100=3,67 \\
& \mathrm{P} 6=[(1 \times 2)+(2 \times 17)+(3 \times 35)+(4 \times 34)+(5 \times 12)] / 100=3,37
\end{aligned}
$$

Next, calculate the mean score of the persuasive dimension obtained through:

$$
\text { Persuasion }=(3,77+3,91+3,86+3,61+3,67+3,37) / 6=3,69
$$

Thus, the dimension of Persuasion has a value of 3.69 is between the IV quadrant which means showing the dimension of persuasion is in the effective criteria

\subsection{Impact Dimensions}

Based on the results of data processing frequency of a number of questionnaires then obtained frequency calculation results as shown below table for Impact dimensions.

Table 7 Frequency Dimensi Impact

\begin{tabular}{lccccc}
\hline \multirow{2}{*}{ Attribute } & \multirow{2}{*}{ Weight } & \multicolumn{5}{c}{ Frequency } \\
\cline { 3 - 6 } & & I1 & I2 & I3 & I4 \\
\hline Strongly agree & 1 & 3 & 2 & 2 & 1 \\
Agree & 2 & 9 & 12 & 15 & 11 \\
Netral & 3 & 20 & 14 & 24 & 28 \\
Disagree & 4 & 44 & 45 & 39 & 39 \\
Strongly disagree & 5 & 24 & 27 & 20 & 21 \\
$\quad$ Amount & & 100 & 100 & 100 & 100 \\
\hline
\end{tabular}

The calculation of the average score is as follows:

$$
\mathrm{I} 1=[(1 \times 3)+(2 \times 9)+(3 \times 20)+(4 \times 44)+(5 \times 24)] / 100=3,77
$$




$$
\begin{aligned}
& \mathrm{I} 2=[(1 \times 2)+(2 \times 12)+(3 \times 14)+(4 \times 45)+(5 \times 27)] / 100=3,83 \\
& \mathrm{I} 3=[(1 \times 2)+(2 \times 15)+(3 \times 24)+(4 \times 39)+(5 \times 20)] / 100=3,60 \\
& \mathrm{I} 4=[(1 \times 1)+(2 \times 11)+(3 \times 28)+(4 \times 39)+(5 \times 21)] / 100=3,68
\end{aligned}
$$

Next, calculate the mean score of the persuasive dimension obtained through:

$$
\text { Impact }=(3,77+3,83+3,60+3,68) / 4=3,72
$$

Thus, the impact dimension has a value of 3.72 is between the quadrant IV which means showing the impact dimension is in the effective criteria

\subsection{Communication Dimensions}

Based on the results of data processing frequency of a number of questionnaires then obtained frequency calculation results as shown below table for the dimensions of communication.

Tabel 8. Frequency Dimensi Communication

\begin{tabular}{lccccccc}
\hline \multirow{2}{*}{ Attribute } & \multirow{2}{*}{ Weight } & \multicolumn{9}{c}{ Frequency } \\
\cline { 3 - 8 } & & C1 & C2 & C3 & C4 & C5 & C6 \\
\hline Strongly agree & 1 & 0 & 0 & 2 & 1 & 1 & 3 \\
Agree & 2 & 8 & 10 & 4 & 3 & 7 & 7 \\
Netral & 3 & 28 & 25 & 17 & 26 & 31 & 29 \\
Disagree & 4 & 37 & 45 & 49 & 50 & 40 & 32 \\
Strongly disagree & 5 & 27 & 20 & 28 & 20 & 21 & 29 \\
$\quad$ Amount & & 100 & 100 & 100 & 100 & 100 & 100 \\
\hline
\end{tabular}

$$
\begin{aligned}
& \mathrm{C} 1=[(1 \times 0)+(2 \times 8)+(3 \times 28)+(4 \times 37)+(5 \times 27)] / 100=3,83 \\
& \mathrm{C} 2=[(1 \times 0)+(2 \times 10)+(3 \times 25)+(4 \times 45)+(5 \times 20)] / 100=3,75 \\
& \mathrm{C} 3=[(1 \times 2)+(2 \times 4)+(3 \times 17)+(4 \times 49)+(5 \times 28)] / 100=3,97 \\
& \mathrm{C} 4=[(1 \times 1)+(2 \times 3)+(3 \times 26)+(4 \times 50)+(5 \times 20)] / 100=3,85 \\
& \mathrm{C} 5=[(1 \times 1)+(2 \times 7)+(3 \times 31)+(4 \times 40)+(5 \times 21)] / 100=3,73 \\
& \mathrm{C} 6=[(1 \times 3)+(2 \times 7)+(3 \times 29)+(4 \times 32)+(5 \times 29)] / 100=3,77
\end{aligned}
$$

Next, calculate the average score of communication dimension obtained through:

$$
\text { Communication }=(3,83+3,75+3,97+3,85+3,73+3,77) / 6=3,82
$$

Thus, the dimension of Persuasion has a value of 3.82 is between the quadrant IV which means showing the dimensions of Communication are on effective criteria.

In accordance with the above calculation results can be calculated the effectiveness of advertising as a whole by using the EPIC method that is: 


$$
\text { EPICrate }=(3,55+3,69+3,72+3,82) / 4=3,70
$$

EPICrate calculation results of 3.70 , when we see in the frequency table above is in quadrant 4 shows that the effectiveness of advertising wardah cosmetics through Vlogger in Bandung can be said to be effective.

When described the results of the effectiveness of advertising through Vlogger by using EPIC method can be seen in the following figure::



Fig. 3. Advertising of wardah cosmetic on EPIC Model

\section{Conclusion}

After doing the discussion above then the conclusion of Wardah Cosmetic product advertisement effectiveness through Vlogger by using the EPIC method consisting of dimension Empathy, Persuasion, Impact and Communication are as follows:

1. Empathy Dimension

In this dimension using 4 questions related to empathy dimension and the average score for empathy dimension is 3.55 , it shows that empathy dimension is effective in promoting Wardah cosmetic product through Vlogger in Bandung.

2. Persuasion Dimension

In this dimension using 6 questions relating to the dimension of persuasion and the average score for the dimension of persuasion is 3.69 , this shows that the dimension empathy is effective in promoting Wardah cosmetic products through Vlogger in Bandung.

3. Impact Dimensions

In this dimension using 4 questions related to the impact dimension and the average score for the impact dimension is 3.72 , this shows that the effective impact dimension in promoting Wardah cosmetic products through Vlogger in Bandung.

4. Communication Dimensions

In this dimension using 6 questions relating to the impact dimension and the average score for the communication dimension is 3.82 , this shows that the dimension of Communication effective in promoting Wardah cosmetic products through Vlogger in Bandung.

5. From the four dimensions of EPIC can be seen that the Communication dimension has the largest average score of 3.82 is proved that the communication made in promoting Wardah 
cosmetic products in the city of Bandung managed to influence consumer confidence to like the product.

\section{Suggestion}

1. Research to analyze the effectiveness of Wardah cosmetics product advertisement through Vlogger in Bandung city in general can be said to be effective however to be more successful again in promoting Wardah cosmetic product hence suggested to do improvement back to each dimension so that effectiveness of advertisement very effective in the meaning of increase of quadrant from IV to quadrant $\mathrm{V}$, so expected to satisfy consumer.

2. Need to conduct a more in-depth study to determine the extent of the influence between each dimension by using the EPIC method in relation to consumer purchasing decisions, not only descriptive analysis but collaboration with statistical tests using multiple linear regression equations in order to obtain the results more accurate

\section{Reference}

[1] I. Bakhri, "7 Hal Mengerikan Jika Kita Lupa Membersihkan Makeup Sebelum Tidur," Wow Uniknya | Melihat Dunia Dari Cerita Sekitar.

[2] "Semiliar Jam Video Sehari Ditonton Pengguna Youtube Di Seluruh Dunia," Tribunnews.Com, 02-Mar-2017. [Online]. Available: Http://Www.Tribunnews.Com/Techno/2017/03/02/Semiliar-JamVideo-Sehari-Ditonton-Pengguna-Youtube-Di-Seluruh-Dunia. [Accessed: 29-Jun-2018].

[3] "Tiga Sosmed Ini Paling Banyak Digunakan Di Indonesia." [Online]. Available: Https://Autotekno.Sindonews.Com/Read/1149935/133/Tiga-Sosmed-Ini-Paling-Banyak-DigunakanDi-Indonesia-1477363605. [Accessed: 29-Jun-2018].

[4] L. Harrie, H. Rahmat, And C. Leni, "An Investigation Of Implementation Samsung Promotion On Media (Youtube, Twitter And Facebook) For Purchasing Decision."

[5] J. E. Lee And B. Watkins, "Youtube Vloggers' Influence On Consumer Luxury Brand Perceptions And Intentions," J. Bus. Res., Vol. 69, No. 12, Pp. 5753-5760, Dec. 2016.

[6] S. H. Achmad And R. Hidayat, "The Effect Of Video Advertisement By Beauty Vlogger On Buying Intention,” Int. J. Account. Finance Econ., Vol. 1, No. 1, Pp. 18-23, 2018.

[7] P. Kotler And K. L. Keller, Marketing Management. Pearson, 2012.

[8] K. Hans-Ruediger, Customer-Centric Marketing Strategies: Tools For Building Organizational Performance: Tools For Building Organizational Performance. Igi Global, 2012.

[9] M. Kartiniasari And R. Hidayat, "Pengaruh Media Iklan (Above The Line \& Below The Line) Produk Indihome Fiber Terhadap Keputusan Pembelian (Studi Kasus Di Bandung Kota)," Eproceedings Appl. Sci., Vol. 1, No. 3, Dec. 2015.

[10] A. Kotler, Prinsip-Prinsip Pemasaran(Kotler,Amstrong) Eds 12 Jilid 2 Erlangga. 2016.

[11] Durianto, Darmandi, Invasi Pasar Dengan Iklan Yang Efektif. Jakarta: Pt Gramedia Pustaka Utama, 2003.

[12] T. Nurhidayat And M. M. Drs. M. Farid Wajdi, "Pengaruh Pelayanan Dan Promosi Terhadap Minat Beli Ulang Pada Hypermarket Assalaam Sukoharjo," S1, Universitas Muhammadiyah Surakarta, 2018.

[13] S. H. Achmad, R. Hidayat, And A. Juwaedah, "Comparative Study Of Price, Service Quality, And Innovation For Buying Decisions: Case Study Lottemart As Hypermarket," Apr-2018. [Online]. Available: Https://Www.Ingentaconnect.Com/Content/Asp/Asl/2018/00000024/00000004/Art00024. [Accessed: 30-Jun-2018].

[14] A. G. Dwianto, M. Iqbal, And R. Alfisyahr, “Analisis Dampak Pemasaran Di Media Sosial Online Terhadap Citra Merek, Minat Beli Konsumen, Dan Net Promoter Score (Pendekatan Eksperimental 
Virtual Brand Following Pada Aplikasi Instagram Produk Fast Moving Consumer Goods@ Erigostore Pada Mahasiswa S1 Un,” J. Adm. Bisnis, Vol. 55, No. 1, Pp. 91-99, 2018.

[15] A. F. Septanto, A. T. Haryono, And C. Harini, "Pengaruh Kualitas Produk, Citra Merk, Persepsi Harga Terhadap Emotional Response Dengan Minat Beli Sebagai Variabel Intervening (Studi Komparatif Terhadap Produk Adidas Dan Nike),” J. Manag., Vol. 4, No. 4, Apr. 2018.

[16] Sugiyono, Buku Metode Penelitian Kuantitatif Kualitatif Dan R\&D - Penerbit Alfabeta. Bandung: Cv. Alfabeta, 2015. 